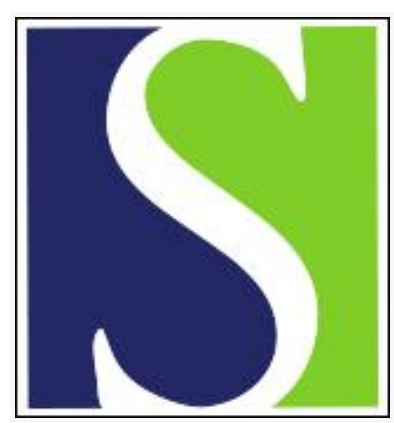

Scand J Work Environ Health 1999;25(5):457

https://doi.org/10.5271/sjweh.460

Issue date: Oct 1999

Association between exposure to potassium aluminum tetrafluoride and bronchial hyperractivity and asthma

by Hjortsberg $U$

This article in PubMed: www.ncbi.nlm.nih.gov/pubmed/10569467

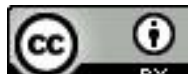




\section{Association between exposure to potassium aluminum tetrafluoride and bronchial hyperractivity and asthma}

There is a possibility of a yet undescribed mechanism that might be involved in the development of occupational asthma in workers exposed to potassium aluminum tetrafluoride. I have observed several cases of bronchial hyperreactivity or asthma among workers exposed to this substance in their work (1). Potassium aluminum tetrafluoride is used as a flux powder in a process of joining aluminum sheets. There is a risk of inhalation of flux particles, most of them being respirable in size. Several exposed workers developed a persistent and worsening cough and wheezing during flux exposure, after a latency time of some months or more, and eventually bronchial hyperreactivity or asthma appeared. This lung affection seems primarily to affect workers with an atopic predisposition. Among workers who developed bronchial hyperreactivity or asthma, I failed to find specific immunoglobulin ( $\mathrm{Ig}$ ) E antibodies against the conjugates of potassium aluminum tetrafluoride with human serum albumin.

Fluoride may be only irritating to the airways, but the exposure levels of potassium aluminum tetrafluoride that causes bronchial hyperactivity or asthma is lower than that causing airway irritation by fluoride exposure.

Although no specific antibodies have been found, there seems to be an allergy-like reaction involved, indicated by the way the patients develop their illness and the selective way by which the bronchial hyperactivity or asthma of some workers worsens.

Aluminum compounds are known to be strong allergy adjuvants and act as nonspecific enhancers of allergic reactions. G-proteins act as a signal carrier from the cell surface receptors to the interior of the cells and affect the histamine release response in the mast cells of an IgE-mediated allergy.

In animal experiments, the combination of alumina and ovalbumin, when alumina was given after ovalbumin injections, substantially increased the serum $\operatorname{IgE}$ and $\mathrm{IgG}_{2 \mathrm{a}}$ levels and the antigen-induced histamine release from mast cells (2).

Furthermore, aluminum fluoride is a potent activator of G-proteins. Members of the heterotrimeric G-proteins are strongly activated by aluminum tetrafluoride (3). Gproteins form stable complexes with guanosine triphosphate and aluminum in the presence of fluoride ion (4). Aluminum fluoride has also been found to stimulate arachidonic acid release and thus increase the production of prostaglandin $\mathrm{E}_{2}$, which has a key role in airway inflammation (5). The cells in the bronchial lining, when exposed to potassium aluminum tetrafluoride, may also be stimulated to increasing the production of interleukins. This occurrence could primarily affect persons with a genetic phenotype that predisposes them for an enhanced ability to synthesize interleukin 4,5 , and 13 $(6,7)$.

Potassium aluminum tetrafluoride may thus, through G-protein activation, have a nonspecific modulatory function in the $\operatorname{IgE}$-mediated immune response.

To my knowledge this model of an enhanced nonspecific allergy reaction has not been proposed in connection with occupational asthma due to exposure to potassium aluminum tetrafluoride.

\section{References}

1. Hjortsberg U, Nise G, Ørbaek P, Søes-Petersen U, Arborelius $\mathrm{J}_{\mathrm{r}} \mathrm{M}$. Bronchial asthma due to potassium aluminumtetrafluoride [letter to the editor]. Scand J Work Environ Health 1986;12:223.

2. Bergstrand H, Andersson I, Nyström I, Pauwels R, Bazin H. The nonspecific enhancement of allergy. Allergy $1983 ; 38: 247-60$.

3. Sondek J, Lambright DG, Noel JP, Hamm HE, Sigler PB. GTPase mechanism of Gproteins from the $1.7-\AA$ crystal structure of transducin $\alpha$-GDP-AIF4. Nature 1994;372:276—9.

4. Goody RS. How G proteins turn off. Nature 1994;372:2201.

5. Buckley BJ, Whorton $\mathrm{AR}$. $\mathrm{Ca}^{2+}$ independent arachidonic acid release by vascular endothelium requires protein synthesis de novo. Biochem J 1994;300:449-55

6. Grünig G, Warnock M, Wakil AE, Venkayya R, Brombacher $\mathrm{F}$, Remnick DM, et al. Requirement for IL-13 independently of IL-4 in experimental asthma. Science 1998;282:2261-3.

7. Wills-Karp M, Luyimbazi J, Xu X, Schofield B, Neben TY, Karp CL, et al. Interleukin-13: central mediator of allergic asthma. Science 1998;282:2258-61.

Ulf Hiortsberg, MD,

Department of Occupational and Environmental Medicine University Hospital

SE-221 85 Lund Sweden

E-mail: ulf.hjortsberg@ymed.lu.se 